\title{
METAPHORS OF RELATIVE ELEVATION, POSITION AND RANKING IN POPOL VUH
}

\author{
Nathaniel TARN and \\ Martin Preghtel \\ Rutgers University
}

This paper is an account of work very much in progress on the textual analysis of Popol Vuh, and is one study among others (since this theme is attracting a number of students today) of inter-connections and mutual illuminations between Popol Vuh and the contemporary ethnographic record in Highland Guatemala and Chiapas.

For some considerable time now Popol $V u h$ has been considered as the major extant text of the Mesoamerican literary traditions, and as one of the most remarkable of all human creation stories, both for its beauty and for the complexity of its cosmological and mythical messages. While it may or may not have had a hieroglyphic original, the present alphabetic version of Popol $V u h$ wars written down somewhere between 1545 and 1558 by an anonymous member of the Cavek lineage of the Quiche Maya of Guatemala. This lineage had been a ruling house until it fell to the Spaniards in 1524. The manuscript was copied by Francisco de Ximénez, a Spanish priest, some 150 years later. While there are references to Christianity in the text, these are few and it is generally regarded as one of the purest extant accounts of prehispanic Maya world-view. At the end of the book, what we call mythical history shades into the historical history of the Quiche, so that the book can serve as an illustration of the extent to which these two kinds of history are not held apart by Maya generally. It is also an ethnohistorical treasury for the comparative study of pre and postcolumbian Maya ideology.

It is the mythical history which interests us most. As not infrequently in these matters, a timetable or schedule of the events described is extraordinarily hard to pin down. We get a sense of progression in the general unfolding of the story but we also note a great many redundancies, repetitions, overlaps, and instances of the story- 
line appearing to bite its own tail. There is a general sense among students of the book that the episodes tell the tale of some four or five successive creations. Yet our own reading keeps on coming up with instances in which characters or events from an apparently "previous" creation to the one being dealt with at that moment are so important, that we might also be dealing with different versions of the same creation. Alternately, creation is incremental: the pattern is fundamentally the same each time though it pushes forward a little in proposing new mediations to problems arising in previous events. The mediations, as one might expect, have to do with such vital matters as the successful ordering of the cosmos into which a successful humanity can then be implanted.

One theme which has preoccupied us for some time is concerned with the fact that while Popol Vuh is extremely un-specific as to original chaos, yet the very succession of arrangements in the myth, so that chaos might be overcome, argues that some version of chaos and its resolution must have existed. Our hunches, and we put them forward as such-not even as hypotheses-would run something as follows. First, it seems to us that there was a problem as to the horizontal repartition of Earth and Water. This in turn was linked to the problem of the sun's apparition on earth: the sunrise being the single most repetitively, exhaustingly, one might say obssessively, awaited event in the whole body of Popol Vuh. The sunrise, in turn, giving all momentum to the processes of plant and human germination, involved a problem as to the vertical repartition of Sky and Earth/Water.

Our hunch is that the Earth was predominatingly $d r y$, dry with the desperate dryness of the Dry season in these Mesoamerican areas, before the sun in his strength rises into the sky and falls in the richest of all his forms: life giving sky-water. Dry also as Xibalba, the land of the Dead from which the counter-heroes of Popol Vuh originate, and dry as the principal pre-human creation in the book: the Wooden men. That everything valuable arises out of water and goes back to water - as we see both in Popol Vuh and contemporary Highland Maya myth - may well be an implication of the sun's path, after sunrise, coming out of the eastern sea and going down into the western sea. There is a division between sun-associated male sky-waters and earth-associated female earth-waters in contemporary Atitlan which may be relevant. The flood which destroys the dry wooden men (or most of them) both in Popol Vuh and contemporary tradition may be an image of the infusion of water into dry land, on the way to a normal creation of corn-men and corn-women. The movement from sea to land of the first ancestors, when created, may reflect the estab- 
lishment of a Wet/Dry season-system as the condition for the accomplishment of normal, life-giving and life-enhancing work. But, rather than prolong these speculations, let us try to work out some implications of this notion that the fundamental message behind many of these Popol Vuh episodes implies the establishment of order as directionality, a concept we know as cardinal (we stress the word) to all Maya thinking. Directionality then implies a locus principle whereby points are fixed relative to each other in an overall scheme. We shall deal more with vertical matters than horizontal ones, partly because we see these more clearly at present, partly because the vertical dimension has diachronic implications of a genealogical nature which may eventually turn out to be of major importance to an ongoing study. ${ }^{1}$

One more initial remark as to method. As you will note immediately, we are interested in the possibility of combining certain methods, mainly of a structuralist origin, as they have arisen in anthropology as well as literary criticism. The main technical term we shall use is "transform", and by that we mean simply that any character, or event or set of such, in relationship (such as a pair of twins) figuring in a textual episode and placed in the same structural situation as another character or event or set of such in another episode, will be considered as transforms of each other. ${ }^{2}$

Now, as to episodes, we will be dealing with four balsic sets. The first has to do with the successive creation of a number of creatures, clearly intended to be proto-human, and their destruction by a creator or creators, because they could not be successfully persuaded to praise such makers. These included animals, creatures of mud or clay, monkeys and wooden men. The weight of the evidence suggests that these, rather than being entirely destroyed, continued to fulfill typefunctions in the succeeding creations such that animals were to clay men as clay men were to wooden men as wooden men were to corn men: slaves if well treated, potentially rebellious and domineering if abused. ${ }^{3}$ Leaving this for further development elsewhere, we pass to

1 We refer here to lineage ranking problems which have been of major interest to the S. U. N. Y.-Albany Central Quiche Project. See, for instance, the discussion in Wallace \& Carmack (1977), especially chapters 1 and 2 and the relevant parts of the Overview.

2 Our "transform" is somewhat different from Eva Hunt's "transformation". Her book was unfortunately not available to us in the field.

3 The possibility of history being prolonged backwards into mythical time is suggested, in another context altogether, by Kubler (1974).

On the survival of wooden men after the flood, not necessarily always as monkeys (see Recinos, 1950: 93, n. 2). We have the feeling that the revolt 
the second episode: that of three giants, a father and two sons: Vucub Caquix and Zipacna/Cabrakan. These are destroyed by the major heroes of Popol Vuh, Hunahpu and Xbalanque. The third episode concerns two main scenarios: one in which Hun Hunahpu and Vucub Hunahpu, senior to the main heroes (actually Father and Uncle), visit the hell of Xibalba and succumb to the Lords of Death, and another in which the major heroes destroy their half brothers Hun Batz and Hun Chouen and turn them into monkeys. Finally, we have the descent into Xibalba of the main heroes, Hunahpu and Xbalanque, their defeat of the Lords of Death, their subsequent effecting of sunrise and moonrise, and (we might take this as a fifth episode if we wish) the human history of the Quiche which streams down from these feats.

We reach our first example with Vucub Caquix in the second episode. This pensonage is a braggart and makes the first of a number of false claims in the text, false claims whereby a pretender to the position of Sun has to be defeated by the rightful owners of that position. Whether Vucub Caquix is Venus or some other astral body, as has been argued, the claim is a likely area of conflict in a situation where the sun has not yet risen. ${ }^{4}$ Vucub Caquix's two sons are criticised likewise for "surpassing the sun / In size / In Importance" (Edmonson, 1971: 53). Of major interest about these two is their structural opposition in that Zipacna is presented to us as a putter-up of mountains while his brother Cabracan figures as a bringer down or leveller of mountains. Popol Vuh thus begins its unfolding of what we might call an immense metaphor of a locus principle by showing how these giants offend against the rule that everything should have its correct, relative place in the cosmos, as well, need it be said, as in the social order. Interestingly enough, each giant is brought down by his own anti-body. Zipacna is tricked to destruction by means of fish and crab, pertaining to the lower world; while Cabracan, the leveller,

of the domestic utensils against the wooden men (Recinos, 1950: 91) as well as the condemnation of the Lords of Xibalba to making domestic implements (Recinos, 1950: 161) may refer to the beings of clay who preceded the wooden men. Compare the animals" rebellion against the "abnormal" work of the Hunahpu/Xbalanque pair later on.

To this day, Atitecas must show the greatest consideration to their domestic implements, as if they were living beings.

4 See, inter alia, Girard (1952: 74). On Vucub Caquix as operating during. the era of the wooden men, see Pickands (n.d.: 38-40). There are myths in Atitlan where rain angels are defeated climbing trees to gather fruit (see Mendelson, 1958: 125, n. 5). 
is tricked with birds, pertaining to the upper world. ${ }^{5}$ The theme of the immeasurable tree, growing ever upwards, which we take as a signal that vertical loci have not yet been established, turns up in Vucub Caquix's favorite passtime of climbing trees to eat fruit (Recinos, 1950: 96) and the baiting of Cabracan with birds on a very high mountain (Recinos, 1950: 105). We will meet other instances as we go along.

It may be that this arrogance of sun pretenders is a metaphor of Dry season superiority in pre-sunrise epochs. In this light, the Giants, the Wooden men of a previous creation and the Lords of Xibalba, all previous to corn-men and corn-women, are in all likelihood transforms of each other. This allows of a curious effect when the Lords of Xibalba complain that the successive pairs of twins are playing ball above their heads. This, surely, could only be unnatural and reprehensible if the distinction between above and below had not yet been instituted: "playing over my head", incidentally, is still an Atiteco saying to this day. The equivalence of Xibalba with previous creation is illustrated by the progress made by Hunahpu/Xbalanque over their fathers Hunhunahpu and Vucub Hunahpu. The progress is that the main heroes, Hunahpu/Xbalanque recognize that the Lords of Xibalba are in fact wooden men: witness the episode in which the main twins meet fourteen beings they recognize as wooden men, the 3rd to 14th of which (i.e. twelve) are the Lords of Death proper. The fathers of the main twins fail to make this recognition and are defeated and killed as a result. Furthermore, the reduction in rank of the Death Lords, when defeated, then becomes clear in terms of their being locked into their true "Dry" locus. The text says: "Only the children of the thickets and desert shall speak with you" (Recinos, 1950: 161; Edmonson, 1971: 140). Now there will never be any need of complaint that children of the upper world play above their heads since this is precisely where they henceforth belong.

If myth does proceed towards ever more adequate mediations be-

5 Note that Zipacna's exploits in the hole may bear relating to the ritual enacted in connection with the pit into which the foot of the Cross is dropped during the Atiteco Semana Santa, as well as to Palo Volador pole pits (Recinos, 1950: 100). Both have agricultural ritual implications. In both the cases of the younger giants-and this is illustrated in Zipacna's by the comments of the 400 boys associated with the Palo Volador-the giants offend against the locus principle while, be it stressed, helping in cosmic ordering. The 400 , after all, have to become stars.

There is a very Asdiwalian note-we refer to Lévi-Strauss's hero studied out of North Pacific myth-in these episodes: death by turning to stone, eating adulterated food, etc. 
tween contradictions, we can perhaps read Popol $V u h$ 's generating of successive pairs of twins ars an ever more successful education or initiation. It is clear that Hunahpu/Xbalanque learn some things from their "fathers" Hun Hunahpu/Vucub Hunahpu, while learning others from their half brothers Hun Batz and Hun Chouen. It is our hunch that what they mainly learn is normal work (Wet/Dry agriculture, seemingly linked to ball-court ritual), imperfectly known and understood by their fathers, and its superiority over abnormal work (the "arts") of which it happens that Hun Bat/Hun Chouen are patrons. ${ }^{6}$ Leaving aside the agriculture/ball court/normal work paradigm for the moment, let us note that Hun Batz/Hun Chouen are defeated by Hunahpu/Xbalanque pushing them too high into a tree in search of edible birds. They can only "resolve" this problem by becoming monkeys. Monkeys, in many places of Highland Maya culture today, are wooden men of past epochs who have survived. It should also, perhaps, be noted that when Hun Batz/Hun Chouen do work, they work abnormally; i.e., they only plant a single ear of corn (Recinos, 1950: 126). In a sense Hun Batz/Hun Chouen "regress" to monkey. hood because they are growing old without having passed through normal work and have not in Maya terms, earned their age. Significantly, the twins' punishment of Vucub Caquix was primarily one of aging him so that his teeth fell out and his skin grew wrinked.?

6 If there is a link between agriculture and the ball-game, then the play of the boys at Recinos, p. 136, is "serious" and "normal"; i. e., "work-play", as opposed to their "non-serious" blowgunning previously. The boys show that they have learned to work through the revolt of the animals, by first clearing the court where their parents had played.

On rats and other animals as survivors of another age (see Edmonson, 1971: 98 , n. 3080).

7 We may conjecture that the monkeys' association with the arts (Recinos, 1950: 109, 130) may be a transform of those elements in the Divinity lists similarly associated (Recinos, 1950: 87-88). On Quiche artisans with a monkey-god patron, see Wallace \& Carmack (1977: 9). The monkeys' attempts at keeping the Hero Twins initially in "nature" and out of "culture" are structurally interesting (Recinos, 1950: 126).

The Twins, of course, do not work until forced to (see note 6). When they begin to understand their "destiny", they wish to stop being assistants to their elders (Recinos, 1950: 127) and make them into assistants (Edmonson, 1971, 11: 2707-9) : one imagines the possibilities of manipulation here in the case of a younger lineage wishing to overturn an older one.

In this connection, it is interesting that Las Casas (quoted at Recinos, 1950: $130, n .11)$ gives us the artist monkeys as younger sons of a primordial couple, without, it is true, specifying whether they have "elder" brothers or not. One supposes they do have. This links with stories about an Atiteco last son, or $c h^{\prime} e e p$, who, in a very similar storv, defeats his elders, the equivalents of the Twins. As we shall see, these co-exist with other Atiteco versions in which Twins triumph over the ch'eep. 
We believe this is linked to the belief that normal work is invariably flanked by two kinds of abnormal work: i. e., the normal achievement of the mature human couple is flanked, on the one hand, by the exuberant play of youth (often animal) and, on the other hand, by the fading, non-work, of old age. These in turn, as Eva Hunt might have taught us - though she may not have seen the bracketing involv, ed- are linked with normal sexuality, bracketed by presexuality on the one hand, postmenopausal lack of sexuality on the other. Both presexuality and postsexuality, incidentally, are linked with magic and/or sorcery - a sorcery, of course, closely linked to "the arts". Whether this relates in turn to the relative impotence of the Equinoxial suns (young Sun/dying Sun) versus the mature summer Solstice sun which fertilizes nature and makes it ready for work, is an open question.

Ideally, we would have liked to illustrate this with examples from the Highland Maya region at large; fresh from fieldwork as we are: Santiago Atitlan is uppermost in our minds. Let us then just say that there is reason to believe that the Atiteco Maximon icon (studied thirty years ago by E. M. Mendelson) incarnates pre-and post-sexuality, and is lord of arts and magic when contrasted along these lines with the solsticial San Martín, as located in the present day Pizom Gagal, or sacred bundle of the Tzutujil Maya (relatives of the Quiche'), the San Martín bundle of Cofradía San Juan in Atitlan (Recinos, 1950: 205; Mendelson: 1958). The Maximon also partakes of the wooden men nature: he is made of palo de pito as are the wooden men; he is lord of dry and night and darkenss, and his female aspect or wife/wives, is the Moon ${ }^{8}$ His decapitation in Atiteco myth may shed light on the decapitation of Hunahpu and Hun Hunahpu during their respective trials in Xibalba, for it does not seem unlikely that all these matters reflect an inactive state of the sun on the dark side of earth, a state which can only metaphorically be known as a death.

We would now like to try to get a little closer to the problem alluded to before: Are these transforms merely repetitive or do increments amount to some sort of progress, some sort of history, perhaps a history which would eventually help explain the passage from myth to history for the Quiche lineages themselves?

It would not be too hard to demonstrate that the original god lists in Popol Vuh are reducible to successive pairs, nor that the mythical

8 The females of the wooden men are made of rushes used in the fabrication of petate tules (Recinos, 1950: 90; n. 1). Atiteco myth has it that the first men ate $t u l$ rather than corn. This, in turn, may be linked to an aquatic origin. 
transforms might range from Hunahpu/Xbalanque to the Quiche gods Tojil/Awilix. In fact Robert Carmack, without this particular theoretical underpinning, has already posited such a step. ${ }^{9}$ Turning to the fourth episode, and considering the Tojil/Awilix binary, we come up with yet another opposition of Day/Sun/Wet and Night/ Moon/Dry, adding skybird to the former and jaguar to the latter. To be more precise we have a quadrilateral arrangement, with a 'Tojil/Jacawitz pair opposed to a Awilix/Nic'aj Tak'aj pair. Tojil of course, is frequently "folded" (to reverse the sense of Eva Hunt's term "unfolding") as when his mountain shrine is said to be surrounded by eagles, jaguars and serpents, with no mention of what the other gods have as guardian animals or nahuales. ${ }^{10}$ Another example is when he appears to the maidens of the resident population the Quiche have invaded as a single principle "Storm". All this concerns the identification of the directions Carmack and other Quicheans identify the gods with: their results being in disagreement with the patterns for Chiapas and for Tzutujil Maya so that discussion is in the offing.

However, we should perhaps avoid this here in favor of another transform: that in which the four first fathers of the Quiche, obviously transforms of the four gods, die and return to the East; not, in our reading, to the fabled city of Tula so much as to the place where the sun is born. ${ }^{11}$ The sons of the first four fathers then follow in their turn by going East to get their insigniae, those laicized variations of

9 We would like to keep further discussion of the Tojil/Awilix complex for a future occasion. In the meantime, the locus classicus is Carmack (1979: 189).

On the opposition of Tojil/Awilix as sky-gods and Jacawitz/Nic'aj Tak'aj as earth-gods, see also Carmack, Fox \& Stewart (1975: 75).

10 There are problems of directionality also involved in these folding/unfolding aspects of the divinity. The episode of the three capes in Popol Vuh (Recinos, 1950: 198-199; Edmonson, 1971: 197-198), associates Balam Quitze with a jaguar cape and Balam Acab with an eagle cape, an association which would have the effect of linking Tojil with jaguar and eagle with Awilix. We would have read the reverse, but it must be noted that this is symmetrical with Carmack's placing of 'Tojil in the West and Awilix in the East.

In the Totonicapan, as quoted by Edmonson (1971: 200, n. 6732), the capes are not attributed to particular ancestors and all the capes do the work, not just the wasp cape. In connection with Mahucutah's original supremacy, it is interesting that, in Popol Vuh, at any rate, it is his wasp cape that kills the maidens' father(s) (see Edmonson, 1971: 175, n. 5772). The episode is reminiscent of the defeat of the Lords of Xibalba by a mosquito, hair of Hunahpu's leg.

On Tojil's folding, see also Edmonson (n. 5786).

The folding mechanism is perhaps also involved in the subsuming of the "sevens" to the "ones" in the various hero pairs.

II Tula and sunbirth may, of course, be unified in the concept of the four Tulans as Carmack following Nicholson, has seen (Carmack, 1968: 67). 
the original ball court accountrements and signs of divinity, from King Nacxit/Quetzalcoatl, who is also Tojil. Note the tautology: if Tojil and Quetzalcoatl are the same, the sons do not go back so much to Tula (a source of endless argument among Mayanists, bearing on the whole nature of the alleged Toltecised invasion of Highland Guatemala) as merely to their divinized fathers to get their ranks. Now, if this is the case, we have a possible misreading of myth as history, and we get closer to a critique of the whole Toltec invasion argument. Archaeology, be it said, might bear us out in its study of the evolution of the native Highland peoples these Toltecs are alleged to have overlaid. That such transforms and repetitions are still at work in Maya belief can be checked against the repeating series of Santiago Atitlan "ancestor myths" containing mytho-historical data ranging from Popol $V u h$ elements to relatively modern Nativistic movements of some 80 years ago.

The closer one looks at Tojil's relation with early mankind, the more steeped in cosmological myth these seem to be. Indeed, the metaphors used in describing defeated enemies, for instance (Edmonson, $1971: 1675 ; 5460-5$ ), could lead us to believe that the humans involved are the corn while the wars are fought by rain, storm, thunder, lighting angels against their Dry season enemies, exactly as such wars are thought to be fought in Atitlan today. The nature of an original fire which Tojil alone possesses is challenging in that it would appear to be a fire from a previous creation ("Yours shall be the lost fire that is talked of") (Recinos, 1950: 176), thus going some way to explaining an otherwise mysterious intervention of "a man from Xibalba" (Recinos, 1950: 177; Edmonson, 1971: 167). We do not mean for us to get drowned in detail but rather to suggest that the lesson here-as has been pointed out in recent exchanges in Maya Lowland studies-is one on how difficult it is to achieve the correct weighing between history and myth.

So much for an example of how the study of Popol Vuh might, if not unblock historical problems, at least suggest healthy doubt. As a third adventure here, we would now like to turn attention to a problem within myth which has interesting diachronic implications. That is the problem of whether age is to carry power-implications or not, with the concomitant implication that age is anterior by definition on any biological time scale.

The answer, again, is a tricky one in that we have suggestions of age/power being handed down to makind from above while, simultaneously, there are others in which they are handed up from below. Furthermore, the above/below binary can be played with and 
inverted at any time: there are no fixed poles, but only -it would seem- a processual interplay between two poles never more than relatively defined or fixed. Such a processual view of a structure so many analysts have sought fixed and invariant explanations for may bring us closer to an understanding of Maya dualism, a perennial problem in our field.

It may well be that it is the archetypal movement of the Solsticial sun standing above the earth and hitting its center for fertilization purposes (the origin, no doubt, of a whole series of beliefs concerned with hitting the muxux, or navel-center in belief, ritual and daily life) that is the model for the imposition of any kind of individual or collective fate from the above onto the below, this goes together with a strong suggestion that the lives and actions of men are isomorphically patterned on those of the gods. The interesting thing in Popol Vuh is that the above, in the pre-sunrise world, is not always what we think it should be. That is, before Xibalba or Hell is fixed in its lower place it seems to be at freedom in the cosmos, and sometimes even to be above the earth. Has it been noticed before that very early in Popol $V u h$ the destruction of the Wooden men is accomplished not just by a flood but by a rain of resin glue from the sky, and that "one called Xecotcovach, comes to gouge out their eyes", Camazotz to cut off their heads, Cotzbalam to devour their flesh, Tucumbalam to mangle their bones? (Recinos, 1960: 90; Edmonson, 1971: 26). And that this is not very different, in a later transform to one fate of Hunahpu when he is finally overcome in Xibalba? Is it by chance that the ball of Hun Hunahpu and Vucub Hunahpu is left as a pledge or hostage in the rooftree of their mothers' house, a height from which it must be recuperated by their sons when they, in turn, go off to play with the Death Lords (Recinos, 1950: 113; Edmonson, 1971: 67). Or that the martyred head of Hunahpu is hung above the ball court until it is recuperated by Xbalanque while the Death Lords are not looking and off chasing rabbits (Recinos, 1950: 152; Edmonson, 1971: 126). Or that the tree of gourds in Xibalba, after the death of Hun Hunahpu and Vucub Hunahpu, hands down, as it were, the birth of this pair's sons, Hunahpu and Xbalanque, together with the wisdom which these sons, transforms of their fathers, will use to triumph where their fathers had failed? 12

12 It does not seem suprising that, if there is a structural relatioship between Ixquic/blood/resin/rubber/ball, Ixquic should in fact be her sons to the extent of virtually vanishing in favor of the ancestral Xmucane.

For and interesting suggestion on the identification of menstrual and foetal blood in Maya belief, see Furst (1976: 182). Note that the mother of Hun 
In the other direction, it is worth underlining that, if death dies in Xibalba-that is, if the Lords of Death are defeated on their own ground it is at the hands of Twins whose mother, Ixquic, was a daughter of a Death Lord and a father who was a semen-producing skull at their conception. (We refer to Hun Hunahpu's defeated skull handing down the semen-spittle - $-\mathrm{a}$ whole paradign there! - to the mother of his sons to be.) The Major heroes are children of death as no other characters in Popol Vuh can be said to be. Blood, quic, is a compound in the names of many of the Death Lords (Recinos, 1950: 141). The boys have so changed, however-and we know it is because they have become mature growers of corn-that Xibalba does not recognize its own progeny when it comes to defeat them (Recinos, 1950: 143). This potent irony of the "Wet" children of "Dry" gods defeating their own origin is but one example of the process we have been trying to illustrate.

It is in this sense that we might read the apotheosis of the Major Heroes when, after defeating the Death Lords, they finally become our Sun and our Moon. If the triumph of the sons takes place, rather than that of the fathers, it is because the sons do not merely rise one level up from Xibalba to the earth's surface. It is the fathers and the gods-Tojil and the like-doubtless transforms of each other, divine ancestors, who get left on earth as stone idols. They are petrified into stone by that very sun, which on its first emergence has a power it will never have again, doubtless because it is all "Dry" as yet, unmodified by the following wetter Moon (Recinos, 1950: 188). ${ }^{13}$

Batz/Hun Chouen dies "early" (Recinos, 1950: 111) somewhat like Ixquic, whereas, in the case of 1 Hunter and 7 Hunter, it is the father who thus dies (Recinos, 1950: 113). These oppositions may be significant.

On the question of a skull/gourd equivalence, see Girard (1952: 105-106). Grains of corn about to be planted, that is, sacrificed, are sometimes referred to as "little skulls" in Atitlan, whereas very young corn plants and other vegetables are called "the little ones".

The relationships semen/spittle/blood/resin/rubber, etc., as well as the pair-1 Hunter's semen comes from a gourd/Ixquic's "heart" goes into a gourd-require working out. There is much suggestion in Girard (1952: 107128). Heart substitutes (Recinos: 122) should be compared to head substitutes: both the gourd-skull of the father(s) and the chilacayote of the sons. Nor in view of the possible pairing of decapitation/castration in Popol Vuh as well as Atiteco myth, should the spittle/semen pair be left unstressed.

Accusations of prostitution against Ixquic in Popol Vuh both by her own parents and by Xmucane are interesting in view of similar accusations against the Virgin Mary and Maximon's "wives" in Atitlan. Parthenogenesis, alas, carries this risk!

13 We are close to suspecting that the turning into idols of the father(s) and the turning of the gods to stone in Popol Vuh may be transforms. The first takes place immediately before, the second immediately after: it is 
Rather, the sons overleap the earth once and for all, go up two steps as it were, to attain and define once and for all in this cycle the consecration of height as Sun and as Moon. In this sense perhaps we can understand the remarkable drawing in Chilam Balam de Chumayel, a Yucatec Maya text. If the roots of the cosmis tree are in Xibalba and its trunk and branches are, in the form of a corn plant especially, the adornment of the middle earth, it is the sun in the sky which is the crown of the world tree.

It is probably the simultaneous positing in Popol $V u h$, and, let it be added, in the contemporary ethnographic record, of an unfixed cosmic state and a relatively fixed one that creates so many puzzles for the Maya ethnologist. In this processual story, we must constantly be aware that one story may be giving us the world in movement; another, the world in a relatively structured state for this time being. In Atitlán, for example, there is a series of myths in which what appears to be an equivalent of the Hun Batz/Hun Chouen pair actual. ly triumphs over the equivalent of the Hunahpu/Xbalanque pair, as well as the more normal series in which the Hunahpu/Xbalanque type pair triumphs. ${ }^{14}$ In a similar vein, the study of the Maximon icon is constantly bedevilled by the question of whether the Maximon is

almost one moment, an almost which needs study. In this connection, see Pickands" stimulating discussion on "acante/acantun" (n. d. 24-31).

Relative to the possible transform status of Tojil/Hunahpu and Awilix/ Xbalanque, see the episode of Tojil and Awilix as young men with the maidens, already referred to in note 10. The presence of Jacawitz oscillates: sometimes present, sometimes absent. Also, despite Totonicapan's three maidens, Popol Vuh has only two temptresses: on "biune" and "triune", see Pickands again (n. d.: 35). Before the bath episode, the three deities start appearing, not as stones, but as "youths" (Recinos, 1950: 192-194).

In regard to origin matters, note that the plunging of the Twins' remains into water is one of the last "acts" in the lives of the major pair.

On the stones speaking when fed with blood, compare the procedure of seating an angel in his stone throne or in his "representante" by Atiteco ajkuna today.

It is interesting to compare mythical episodes and actual war techniques of the Quiche; see the use of the wooden men decoys, the use of gourds full of wasps, etc. (Recinos, 1950: 201). The Totonicapan quotation in Edmonson (1971: 208, n. 7026) reminds us of a legendary Atiteca nativistic use -by the prophet F. S.--of twelve wooden "executive puppets" around the year 1900. The functions of these seem most frequently to decoy people away from the prophet himself. Thus a puppet will frequently take a victim's place in prison. Prison myths, harking back to Popol Vuh, are characteristic of various cycles in all stages of Atiteco "history". The Maximon will take peoples' places in prison in certain stories.

14 We believe it most important to note that, in fact, no one is ever really the victor or the vanquished in these battles. Every protagonist becomes an important aspect or function of the universe, unique and valuable provided he stays in his locus. 
ch'eep, or last born youngest son, or whether he is the rilaj acha, the old man or old god. In fact, of course, he is both in different times and at different loci. One dimension of this is the fascinating birth/ death symbolism of the hanging of the Maximon during Holy Week. On the one hand, he is hung as Judas Iscariot, traitor to Christ, dying also at the same time on his Gross. On the other hand, a rich symbolism of the rope as an umbilical cord suggests that he may be being born, as, indeed the Christ is in the very process of his death. That all of this involves a tree symbolism which may be related to the cosmic tree linking Hell, Earth and Sky makes it all the more fascinating. We need hardly stress that the tree is in turn related to the corn plant around which all of Maya myth ultimately revolves. ${ }^{15}$

The resolution, one supposes, must come in terms of recognizing the simultaneous operation of a cyclical process and a linear-evolutionary process, with the cyclical process priming. That is to say, we have to account for the fact that the sons triumph over the fathers in some linear sense, but stress also that such a triumph is built into the regularly recurring cycle of all existence. In this sense we would have to take it that age and anteriority are both more and less powerful than maturity (exemplified by the Major Heroes) in that they frame maturity, or, as we said before, bracket it. Each positive state-maturity--is framed by two relative negatives: extreme youth (immaturity) and extreme age (over-ripeness). Since these have a habit of turning into each other cyclically in most Maya myths to form maturity, we have, finally, to invoke the Locus Principle again: it is by age and youth and maturity being in their right places in relation to each other that the world can keep going rather than that anything should be decisive in the very nature of age, or youth, or maturity, per se. None of this is too surprising in overall human terms. What is interesting in

15On cosmic trees and the origin of lineages and umbilical cords, see Pickands (n. d.: 7-13, 22-44). A considerable amount of new information on tree-birth will be forthcoming from new Atiteco data. New information on Maximon's female aspects in relation to weaving is also valuable in this respect.

The corn stalk (or reed in Recinos, 1950: 139) planting episode before the Twins leave for Xibalba generates a whole series of equivalences between various "navels" of earth and sky in Atitlan, including one in the church (the Holy Week cross-pit); one in the Cerro de Burro, principal residence of the nuwal tak achi", and one in every house. Stress on planting in the "dry" soil of the house as opposed to the "wet" soil of the fields may relate the episode paradigmatically to the dryness of Xibalba. There is at least the suggestion that "dry" houses may have existed before "wet" fields, with the concomitant that "culture" may be "dry", "nature' "wet". The animals' refusal of what may be seen as "dry" work on the part of the not yet enlightened Twins may be part of such a paradigm (see Edmonson, 1971: 109-109). 
the Maya case is the particular framing device which is so confusing at the first approaches. The importance of right-placing, of course, needs no stressing to anyone familiar with the extreme hierarchization of Maya society. ${ }^{16}$

There is much evidence in Mesoamerican mythology which would allow us to take the sky as youth and the underworld as old age, both of them framing the earth's surface as youth and old age frame maturity. As in Buddhism it may be suggested that the human condition is the only possible incarnation. An attractive image with which to leave this section might come from tree symbolism where we would be provided with a dual orientation of age and anteriority. These arise from the roots of creation because that is where they begin in the youthful seed but, insofar as the sky is youth, age and anteriority can be handed down from the sky, also in the sense of growing out of it. Whether it be the skull fruit hanging down the seed of the Major Heroes from the tree top, or the old god hanging from it by his neck, we are given a reverse image not too different from our own depictions of lineage branchings. And, of course, if we have trees expanding upwards indefinitely in a previous creation, it is because nothing has as yet been fixed in its proper locus.

A final exploration of a theme here turns on yet another problem: that of the relation between male and female. Concentrating now on our principle couple, Hunahpu and Xbalanque, we must point out that arguments about whether Xbalanque is a male or a female are one of the cruxes of Maya scholarship still. There is the controversy about whether the initial $\boldsymbol{X}$ is a diminutive or a possible sign of femaleness; there is also the widespread notion that Xbalanque, if taken as male, must be Venus rather than the Moon. Both Recinos and Edmonson take Xbalanque as a male moon (Recinos, 1950: 162-3; Edmonson, 1971: 142-144) while Girard, a fascinating if eccentric student of the matter, unequivocally takes the figure as female. ${ }^{17}$ Let us then, turn to another characteristic of Xbalanque which is less of.

16 In the ultimate analysis, it is probable that the gods of heaven and those of hell are transforms, just as 1 Hunter and 7 Hunter, to speak Edmonson instead of Recinos, are transforms of 1 Death and 7 Death. Sky, earth and underworld being all part of one cycle, we realize that if the notion of Xibalba as the place of death/rebirth of seed is taken at full value, the Lords of Death must be defeated not because they are less deserving than the Twins (and, in that spirit, the Twins go down to play with them on their own level) but because they have to be in their own place and not on high for the world's business to be done.

17 See, inter alia, Recinos (1950: 94, n. 1); Girard (1952: 151, 153, 167, 192-4); Cohodas (1974: 105-107 and 1976: 160); Pickands (n. d.: 65-68). 
ten a subject of comment, and note that Xbalanque is always the assistant of Hunahpu. Whether we think of the episode in which Hunahpu loses and regains his head in Xibalba or that in which Hunahpu is cut up and put together again by Xbalanque, everything happens as if Xbalanque were a kind of conjurer's aid to Hunahpu. Lest it be thought that these are dead issues, let us say that one version out of many of an Atiteco myth gives us a Hunahpu transform and a Xbalanque transform coming to a crossroads. The Hunahpu figure, male, chooses the sky road which is straight, and becomes the sun while the Xbalanque tranform, also male, chooses the earth or mountain-valley, road which is winding and crooked. Xbalanque is then moon. Two sisters follow them: the older becomes the Morning Star on the sky road; the younger, saying she prefers "life and fun and sex", chooses to become the life-road star, probably the Venus as Evening.

Well and good. We know, on the other hand, that the ritual unit of Mayakind is a husband and wife: ceremonial life does not start for a Maya until he is wived. Less stressed, perhaps, is the fact that almost any Maya official to this day has a number two who is considered as his assistant — he who works while no. 1 commands - and without whom he cannot move through any ritual. In Atitlán it may be the Primer Fiscal of a Cabecera, or in turn, the Fiscal's Segundo Fiscal. Or it may be the 4th cofrade to a first cofrade in the saint's brotherhoods system, the 2 nd to a 5 th the 6 th to a $3 \mathrm{rd}$. Or again, the personal alguacil to a mayor. The situation is also thought to exist among saints (santos), who often go ritually, processionally, in pairs, even to the extent of being known as twins. Sometimes the assistant is known as the leader's "dog", much as a woman's kitchen tools are her "dogs", and a woman might be referred to as the "dog" of a man.1B What is also true is that a male assistant, in ritual and even in everyday metaphorical language, will be known as his number one's "wife". ${ }^{19}$ Could this complex of ideas be in any way responsible for the ambiguous position of Xbalanque and beyond him/her of all assistants or number two's in ritual situations?20

I8 On the dog, see Wallace and Carmack (1977: 7).

19 There are many other metaphors. One often refers to one's body as one's "wife". In effect, everything on earth has a dual male/female nature with relative predominance of one quality over the other. Everything attached to a male does not have to be male, nor everything attached to a female, female.

20 In some cases, such as that of Hun Batz/Hun Chouen, the no. 2, almost disappears into the no. 1: see Cohodas (1976: 164); Recinos (1950: 92, 108, n. 2); Edmonson (1971: 30); Gossen (1974: passim).

It should also be stressed that 1 Hunter and 7 Hunter are also frequently 
However, there is more. We notice throughout Popol Vuh a number of examples in which the last of a series of leaders is occasionally wived, occasionally wifeless, according to different places in the text, sometimes according to differences between Popol Vuh and a kindred text such as Totonicapan. Our first example is, of course, Vucub Hunahpu (Recinos, 1950: 108), followed by Iqui-Balam (Recinos, 1950: 170 , n. $2 ; 175$, n. $6 ; 176 ; 183)$. But there are others even as far down as King Qocavib who, being wifeless, has a child by his brother's wife (Recinos, 1950: 209, n. 7; 239; Edmonson: 215, n. 7 258). More difficult to explain, perhaps is the case in Memorial de Sololá of 13 men and 14 women, the last woman being "extra" (Recinos, 1953: 46). The notion seems to be that a ch'eep or last' born of any series of siblings-usually male-tends to be a bachelor. In Atitlan, many of the major episodes in the ancestral myths turn on this bachelorhood; it is even the case that the Maximon is created in order to cope with disorders brought about by the non-maxital sexuality of the bachelors. In some versions, the ch'eep, though married, is a preferred victim of adulterers. Maximon himself, while he has two women (transforms of each other and in some cases called "whores"), is firmly alleged not to be married. It would seem as if, in contrast to the world of the San Martín icon in which normal work, normal sexuality and normal procreation are standard, the world of the $c h^{\prime}$ eep Maximon (sometimes, nota bene, the ch'eep of a series of twelve Martins...) is firmly bachelorial, and to that extent given up to pleasure, fun, gaudiness, license and sexual magic.

The question seems to become: Is the $c h$ 'eep unmarried because he is in some sense(s) a woman himself? Is Xbalanque such a ch'eep? is the evidence linking Maximon to some extent with a female/bisexual/homosexual/transvestite paradigm part of all this? And if there had been any question of marriage in Popol $V u h$, would we have found, in a male definition of the pair, Hunahpu married while Xbalanque were not? The question is of interest not only to myth but also because it abuts-like many of these reviewed here-on a problem in Quiche lineage history. But that had better be left for another occasion. ${ }^{21}$

subsumed under one heading (eg. Recinos, 1950: 120, 124; Edmonson, 1971: 77).

This subsuming may be an aspect of pairs that have not yet fallen under the rules of this "working" creation.

21 On the Ahpop C'amha as "assistance" to the Ahpop, see Wallace \& Carmack (1977: 14). Note that the "illegitimacy" taint of the former's lineage seems linked to the question of Qoacaib \& Qocaib. It is a question whether that "adultery" episode enters into "adultery" episodes in Atiteco myths. 
In conclusion, we have reviewed a number of instances of a logic of relative height, position and ranking which primes over any ethic discernible in Popol Vuh. We mean by this that if posicion, locus, primes over inherent nature, we have to be dealing with a logic rather than an ethic. The discussion tries to show that many individuals, or rather pairs of individuals, are transforms of each other working, in structuralist terms, towards ever closer mediations. We have suggested the idea that the successive episodes of Popol Vuh intnoduce order into the universe, the same order as Maya society exhibits now. In the same way as it may be that creation previous to that of Corn-humans consisted in a "dry" Xibalba which had to be wetted by the sea in order that we and alternating seasons might be created for normal working purposes, so it may well be that the relative degrees of height had to be fixed into underworld, earth-surface and sky so that the various powers might move around in these directions for any given cosmic area or period of fruitful occupation. It appears to emerge that the role of previous creations, or beings originating in them, is more elaborate than may have been thought: Maya genesis talks little of chaos, but it can be inferred - and it is then understood- that Genesis, as so often elsewhere, both leads to the creation of order in the present universe while leaving powerful residues in the shape of previous gods, debts to the creator (perhaps in the form of sin) and potential disorders of various kinds. Another suggestion here is that mythical and historical data may complement rather than exclude each other in the important sense that Maya ideology takes seriously the reality of micro and macrocosmic time correspondences, as well as various versions of the doctrine of Eternal recurrence. In this sense, it may be difficult to attain a reading of Popol $\mathrm{Vuh}$ without considerable experience of Maya ethnography at first hand. Finally, we hope to have confirmed yet again the fact that no scheme or schemata which fail to take Maya dualism into account can justly deal with all the aspects of Maya sacred paradigms. But this dualism must be viewed all the time as processual. The echo of a binary structure which is the ternary that keeps this duality in movement must never be lost sight of for a single moment.

\section{BIBLIOGRAPHY}

Garmack, R. M.

1968 "Toltec Influence on the Postclassic culture history of Highland Guatemala". In Archaeological Studies of Middle America, pp, 42-92. Middle American Research Institute, Publ. 26. 
Garmack, R. M., Fox, J. W. \& Stewart, R. E.

1975 La formación del Reino Quiché. Guatemala: Instituto de Antropología e Historia de Guatemala, Publicación especial, no. 7.

Cohodas, M.

1974 "The Iconography of the Panels of the Sun, Cross \& Foliated Cross at Palenque, Part II". In Primera Mesa Redonda de Palenque, Part I, pp. 95-108. Pebble Beach, California: The Robert Louis Stevenson School.

1976 "The Iconography of the Panels of the Sun, Cross \& Foliated Cross at Palenque, Part III". In Segunda Mesa Redonda de Palenque: The Att, Iconography B Dynastic History of Palenque, Part III, edited by Robertson, M. G., pp. 155-176. Pebble Beach, California: The Robert Louis Stevenson School.

Fox, J. W.

1978 Quiche Conquest: Centralism \& Regionalism in Highland Guatemalan State Development. Albuquerque: The University of New Mexico Press.

Furst, P. T.

1976 "Fertility, Vision Quest \& Auto-Sacrifice: Some Thoughts on

Ritual Blood-Letting among the Maya". In Segund"a Mesa Redonda de Palenque: The Art, Iconography $\mathcal{E}^{\circ}$ Dymastic History of Palenque, Part III, edited by Robertson, M. G., pp. 181194. Pebble Beach, California: The Robert Louis Stevenson School.

Girard, R.

1952 El Popol-Vuh, fuente histórica, Tomo 1: El Popol Vuh como fundamento de la Cultura Maya-Quiché. Guatemala: Editorial del Ministerio de Educación Pública, Colección Contemporáneos, no. 30.

Gossen, G.

1974 Chamula in the World of the Sun. Cambridge, Mass.: The Harvard University Press.

KuBLer, G.

1974 "Mythological Ancestries in Classic Maya Inscriptions". In Primera Mesa Redonda de Palenque, Part II, edited by Robertson, M. G., pp. 23-44. Pebble Beach, California: The Robert Louis Stevenson School.

Memorial de Solola

1953 The Annals of the Cakchiquels. Translated by Adrian Recinos \& Delia Goetz. Norman: The University of Oklahoma Press.

Mendelson, E. M.

1957 Religion and World View in Santiago Atitlan. Chicago: The University of Chicago Library Microfilm Collection of Mss. on American Indian Cultural Anthropology, no. 52.

1958 "A Guatemalan Sacred Bundle". In Man, vol. LVIII, no. 170, August. London: The Royal Anthropological Institute.

- 1959 "Maximon: an Iconographic Introduction". In Man, vol. LIX, no. 87, April. London: The Royal Anthropological Institute.

1965 Los escándalos de Maximon. Guatemala: Seminario de Integración Social Guatemalteca, Publicación 19.

Pickands, M.

n. d. The Mythological Origins of the Maya Cross. (Working Paper, Department of Anthropology, S. U. N. Y., Albany, N. Y.) 
Popol Vuh

1950 Popol Vuh: The Sacred Book of the Ancient Quiche Maya. Translation by Recinos, A.; Goetz, D. \& Morley, S. G. Norman; The University of Oklahoma Press. (Recinos: 1950.)

1971 The Book of Counsel: The Popol Vuh of the Quiche Maya of Guatemala. Translated by Edmonson, M. S. New Orleans: The Middle American Research Institute of Tulane University, publication 35. (Edmonson, 1971.)

WAllage, D. T. \& Carmack, R. M.

1977 Archaeology and Ethnohistory of the Central Quiche. Albany: The State University of New York Institute for Meso-American Studies, Publication no. 1.

Hunt, Eva

1977 The Transformation of the Hummingbird: Cultural Roots of a Zinacantan Mythical Poem, Cornell University Press, Ithaca and London. 